Article

\title{
"Green" Information Promotes Employees" Voluntary Green Behavior via Work Values and Perceived Accountability
}

\author{
Ping-Ju $\mathrm{Wu}^{1}{ }^{1}$, Tung-Ju $\mathrm{Wu}^{2}$ and Kuo-Shu Yuan ${ }^{3, *}$ \\ 1 School of Economics and Finance, Huaqiao University, Quanzhou 362021, China; wbr@hqu.edu.cn \\ 2 School of Management, Harbin Institute of Technology (HIT), Harbin 150001, China; tjwu@hit.edu.cn \\ 3 Business School, Huaqiao University, Quanzhou 362021, China \\ * Correspondence: yks1125@hqu.edu.cn
}

Received: 29 August 2019; Accepted: 4 November 2019; Published: 12 November 2019

\begin{abstract}
A range of different approaches has been used to involve employees in green workplace initiatives. One example of such an approach is to spread awareness by displaying "green" information concerning work-related environmental protection and sustainability information on organizational bulletin boards. The study aims to examine how green display rules and felt accountability influence the relationship between new-generation employees' work values and green behavior. There were 567 Chinese millennial employees who participated in this study. The results showed that intrinsic preference, interpersonal harmony, innovative orientation, and long-term development had a positive influence on employees' green behavior through the effect of felt accountability. Besides, the more green information displayed, the stronger the effect of intrinsic preference, interpersonal harmony, and long-term development on employees' green behavior. This study provides valuable insights for managers to understand the work values of the new-generation employees and, in turn, improve their green awareness, which can help execute corporate social responsibility.
\end{abstract}

Keywords: felt accountability; green behavior; new-generation employees; work values

\section{Introduction}

Threats to the environment have become some of the most important issues facing the world $[1,2]$. Organizations nowadays worry more about the natural environment than they did in the past $[2,3]$. Because of the growing concerns about the long-term adverse effects of environmental degradation and climate change, companies over the world are endeavoring to support environmental responsibility [1,4]. In addition, companies may benefit from increasing sales, branding recognition, and desirable employee outcomes if they successfully employ green policies to promote environmental sustainability $[2,5,6]$. Employees are those who implement organizational green policies; therefore, it is necessary for organizations to promote and ultimately change their behaviors and ensure that such behavior is consistent with organizational green goals $[3,7]$.

Behaviors employees engage in that are aligned with environmental sustainability are referred to as "green" behaviors [3]. This definition includes both organizational citizenship behaviors for the environment (OCBE) [8] and task-related pro-environmental behavior [9]. Ones and Dilchert [3] note that even though green behaviors are mostly voluntary, it is important to consider behaviors related to job tasks. Therefore, in line with Kim et al., [1] which builds on Boiral [10], we view voluntary green workplace behavior as a type of organizational citizenship behavior. Our theoretical model is grounded in the corporate social responsibility literature, which suggests that some normative motives may affect the participation of social responsibility, such as the match between personal values and the issues concerned [4]. 
Voluntary green behaviors have long been studied in nonwork settings; organizational scholars have just begun investigating the antecedents of voluntary green workplace behaviors [1]. Yuriev et al. [11] also point out a growing interest in pro-environmental behaviors in the workplace. Traditionally, green behavior and its antecedents have been examined in nonwork settings by environmental psychologists [12]; however, it is worth studying voluntary green behavior in the workplace because differences between work and nonwork settings may limit the generalizability of findings [1]. Among those studies on green workplace behavior and its antecedents, individual characteristics, such as personality [13], and contextual factors, such as leaders' leadership styles [9], have been found to influence employee green behaviors. However, as yet, little is known about how these individual factors combine with contextual factors together to influence employee voluntary green behaviors [1].

Among all the barriers that impede employees from voluntary green behaviors, attitudes towards pro-environmental activities is the most reported one [11], including moral obligation and personal values. Personal values are a set of psychological characteristics that are particularly relevant for understanding motivation [14,15]. Because the current study aims to understand voluntary green behaviors in the workplace, we focus on work values, an important subset of values, defined as the evaluation criteria related to the work or work environment through which individuals can identify what is "right" or assess the importance of preferences that reflect their own attitudes about their work and further influence their behaviors [16,17]. In other words, they are norms that employees use to judge and to choose among alternative modes of behavior [18]. Work values may differ due to cultural divergence and result in different ultimate actions/behaviors. Therefore, some of the well-established dimensions of work values may not be applied to Chinese workplaces. For example, Western scholars usually divide the work value structure into internal and external factors $[19,20]$. Yet the work values of China's new generation (born from the 1980s to 2000 [21,22]) cannot be clearly characterized according to internal or external factors [23]. Jiang and Yang [24] have suggested that the influence of the social environment on work values is so strong that there may be substantial differences between dimensions of Western work values and those of Chinese work values. The work values of Chinese millennials not only include internal or external factors, but also encompass behavioral drivers that promote organizational development and self-achievement $[16,25,26]$, which include five dimensions: Utilitarian orientation (i.e., material rewards, which stresses the self-material repayment of work), intrinsic preference (i.e., the social significance and satisfaction from the work itself), interpersonal harmony (i.e., the importance of harmonious interpersonal relationships in the workplace), innovation orientation (i.e., the tendency to have novel ideas, strong creativity and imagination, and daring to challenge tradition), and long-term development (i.e., occupational prospects over a long period) $[16,23]$.

Felt accountability has been linked to desirable employee outcomes and it can be simply described as a person's perception of their personal responsibility to others [27]. Perceived accountability is important because it can help induce employees' green workplace behaviors. When employees are accountable and held answerable for their own behaviors, they are more likely to act in a way that is desired or admired by others in order to protect and enhance their self-images [28,29].

The present study attempts to fill the gap by theorizing about personal psychological characteristics (i.e., employee work values) and social conditions (i.e., green display rules) likely to be associated with the voluntary green workplace behavior of individual employees. The urgency of environmental issues has spurred a large volume of research on the psychological underpinning of support for pro-environmental actions in recent years, generating theories and empirical evidence regarding psychological factors related to pro-environmental engagement [30]. Yet the databases are heavily biased toward Western populations, which raises concerns about the generalizability of the findings [31], and this bias may be a critical barrier for addressing issues related to the global environmental crisis. The purpose of the current study is two-fold. First, we propose that employee work values provide important insights into the motivational bases of voluntary green workplace behavior. Drawing on self-verification theory [32,33] and social information processing perspectives [34], this study aims to 
explore the relationship between work values and felt accountability among Chinese millennial workers. More specifically, we attempt to examine whether the work values of Chinese millennial employees motivate their value-consistent green behaviors through perceived felt accountability. In addition, we seek to extend the understanding of the contextual factors that impact value activation by focusing on green display rules, which refer to employees' perceptions of job demands for environmental sustainability. As green information concerning environmental protection and sustainability is displayed on the organizational bulletin boards, we propose that green display rules play a key role in the activation of work values and the values-to-workplace behavior relationships. Second, because of the contextualized nature of work values, new generations of Chinese employees born in the Internet era are deeply influenced by the global economy, and hence may demonstrate unique and multidimensional work values, such as focusing on profit returns and internal preferences, emphasizing equality, justice and long-term development [25]. With the rise of the sharing economy, millennial employees represent a significant part of the Chinese workforce and have potential opportunities to redefine and shape organizations [35]. While the majority of studies on voluntary green workplace behavior were mainly conducted in Western countries, the findings might not be applicable to Chinese millennial employees as they demonstrate different characteristics and behaviors compared with older generations and millennials living in other countries [25,35,36]. Given the Chinese workforce is the largest in the world, it is worth discovering how to promote Chinese millennial employees' green workplace behaviors based on their unique work values. However, to our best knowledge, no prior studies have explored the relationships between work values of the Chinese millennial generation and voluntary green workplace behaviors, the underlying motivational mechanisms, as well as how contextual factors influence such relationships. By identifying felt accountability and displaying green rules that may stimulate employees' underlying motives for green behaviors, our work adds another theoretical route for inducing employee voluntary green workplace behaviors, and also contributes to an improved understanding of OCBE.

\section{Research Model and Hypotheses}

The study aimed to examine how green display rules at work influence the relationships between work values, felt accountability, and green behavior among a new generation of employees. Drawing on self-verification theory [32,33] and social information processing perspectives [34], we developed our research model (see Figure 1) and hypotheses as elaborated in the following sections.

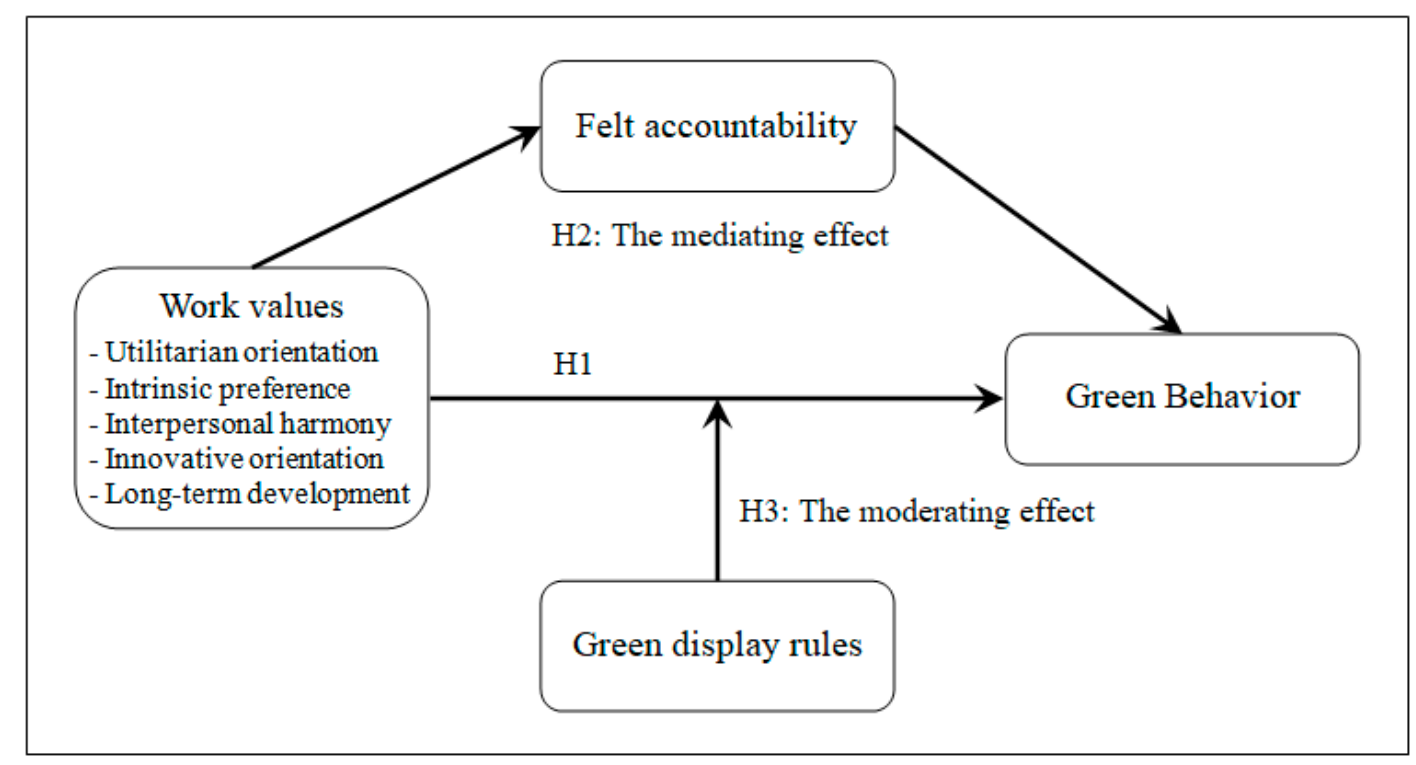

Figure 1. The framework of the effect of green display rules on the relationship between work values, felt accountability, and employee green behavior. 


\subsection{Work Values and Employee Green Behavior}

Ones and Dilchert [3] define employee green behavior as scalable actions and behaviors employees engage in that contribute to environmental sustainability. Employee green behavior includes activities such as saving energy, using resources efficiently, avoiding waste, recycling, and conserving water [3,37]. Kim et al. [1] define voluntary green workplace behavior as employee actions that are environmentally sustainable for the employer organization but are not subject to any formal environmental management policies or systems. The voluntary green behaviors that occur in workplace environments and the underlying motivations that guide such behaviors may have implications for how individual differences and social dynamics affect voluntary green behavior.

The study of work values stems from people's discussion of the concept of values. Most researchers believe that values are a choice of goals or guidelines and standards of long-term stability, and that values evolve with cultural, social, and personality changes [38-40]. In other words, work values may differ due to cultural divergence which may result in different ultimate actions/behaviors. For example, Chinese work values demonstrate that the new generation of Chinese employees pay attention to personal interests, emphasizing the fulfillment of intrinsic preferences and interpersonal harmony, and expecting to achieve a complete career through long-term development and self-innovation.

Self-verification theory [32,33] provides some indication as to why personal values provide insights into the motivational underpinnings of prosocial behaviors. According to self-verification theory, people seek out and create opportunities to verify their self-beliefs, and to reconcile their self-beliefs with the perceived views of others if there exist differences. When people's behaviors are aligned with their self-views, they experience feelings of control and confidence; on the other hand, when they engage in behaviors that contradict their self-views, they feel anxious and uncertain [41]. As such, engaging in value-consistent behavior validates beliefs about the self and thus enhances self-confidence [14]. Hou and $\mathrm{Lu}$ [25] argue that the work values of intrinsic preferences, innovative orientation, and interpersonal harmony encourage the new generation of employees to maintain positive self-views. When employees work in a manner that is consistent with their positive self-views to create feelings of confidence, it may lead to interpersonal altruism in the workplace [41], and, in turn, promote employees' prosocial behavior, such as green behavior. When working in an environment that matches their self-values, employees with intrinsic preference will have greater value verification and, thus, engage in altruistic green behavior consistent with positive self-views. When a utilitarian-oriented employee has a high long-term orientation, he/she expects to receive opportunities for promotion and career development, and to be able to pursue his or her accomplishments over a long-term career life, rather than in the short run [23]. In other words, in order to weaken the uncertainty and insecurity in the workplace competition, individual employees with utilitarian orientation (i.e., material rewards) and long-term development values (i.e., occupational prospects over a long period) are more willing to engage in green behavior, in order to maintain stable team relations, and strengthen their positive self-views. Therefore, we propose the following:

Hypothesis 1. New generation employees' work values (utilitarian orientation, intrinsic preference, interpersonal harmony, innovative orientation, and long-term development) have an influence on employee green behavior.

\subsection{Felt Accountability as Mediator}

Felt accountability refers to the perceived expectation that one's decisions or actions will be evaluated by some salient audience(s) [42]. The resulting rewards or sanctions are believed to be contingent on this expected evaluation [42-44]. Employee accountability is important in that it is calculated in terms of positive behavior that contribute to the success of the organization $[43,44]$. Accountability can be divided into two types: Procedural versus outcome accountability [45]. Under procedural accountability, individuals are held answerable largely for the standards and/or processes they develop. On the other hand, under outcome accountability, individuals are held answerable for 
the quality of their decisions, or the quantity of goods/services produced, rather than the processes used to secure these outputs. To sum up, when individuals are accountable, they are held answerable for their own behaviors. These "accounts" are important, as actors seek to use them in order to protect and enhance their self-images. This is so because individuals are concerned about their image and status and seek approval in the eyes of others [28,29].

According to the social information processing perspective [34], individuals make sense of their environment based on processing the social information in the workplace. Such sense-making takes place in a social environment in which norms and expectations influence the rationalization of behavioral development, which can be described as a process of legitimating behavior. Because people are driven to build and maintain their self-images [29], this motivation has a major impact on a person's response to specific responsibility requirements. This influence has both positive and negative effects, because people tend to view individuals in a way that is consistent with the image they hold and want to portray. People develop acceptable justifications for their own behaviors as a way of making such behavior meaningful. Justifications serve to provide a reason for performing any action which is consistent with the personal values. Therefore, such justifications are necessary for making sense of related behaviors. In other words, felt accountability is a necessary mechanism for an individual employee to engage in value-consistent interpersonal behaviors (i.e., self-verifying process) as it creates cognitive consistency and provides an opportunity to receive evaluations that confirm employees' self-views. When employees attempt to engage in altruistic green behaviors that are consistent with their work values, they are held answerable for their own behaviors first, as a mechanism to activate their cognitive awareness, and in turn create an opportunity for them to receive evaluations that confirm their own self-views. Therefore, we propose the following:

Hypothesis 2. New generation employees' perceived felt accountability mediates the relationship between work values and green behavior.

\subsection{Display Rules as Moderator}

Display rules have been conceptualized as role requirements of particular occupational groups (e.g., emotional worker) and interpersonal job demands [46,47]. In the current study, we focused on the definition of interpersonal job demands as we studied employee green behavior at workplaces in general, instead of limiting to a specific occupation. We defined green display rules as the perceived job demands for employees to display green-related behaviors in one organization. The job-demands approach allowed for variance in the interpersonal requirements of work to exist within occupational categories and reside in specific jobs [47]. For example, interpersonal job demands may refer to the effective interactions with clients in a service context, because the display rules regulate the delivery of the interaction between the service representative and the client. Supervisors are likely to be important definers of display rules at the workplace, given their direct influence on employees' beliefs about job performance expectations [48]. According to social information processing theory [34], employees' perception of interpersonal demands inherent in display rules may depend on supervisors' views on how important they are.

Social information processing theory suggests that employees' perceptions of job demands are influenced by what people around them think. In other words, employees build their perceptions and attitudes in society based on social cues in the workplace, which in turn affects their behavior [34]. For example, supervisors who place greater importance on interpersonal job demands may signal to employees that they are important to the job, and then employees may mirror their supervisors' concerns and pay more attention to the interpersonal aspects of their job $[34,46]$. The significance and importance of interpersonal work requirements may trigger employee self-regulation activities to monitor their own compliance with display rules. Therefore, contextual factors such as display rules play an important role in activating values and strengthening or weakening values-to-behavior relationships $[15,49]$. The recognition of relevant cues raises self-awareness about personal values and 
self-concepts. In addition, cues suggesting social acceptability or encouragement contribute to value expression, while cues suggesting social inadequacy restrict value expression [15]. That is, when an individual employee's work values are consistent with the given green display rules, their values are perceived as acceptable and encouraged in the organization, which facilitate their value-verification and in turn strengthen the values-to-behavior relationship. On the other hand, if their work values are perceived as socially inappropriate in the organization, the values-to-behavior relationship may be weakened. For example, for the new generation of employees who value interpersonal harmony, in order to obtain the legitimacy and status of the organization, they will ensure their behaviors to be consistent with the organizational requirements or the expectations of the work group; therefore, they are more willing to participate in environmental protection and resource recovery in the workplace. For new generations of employees who value their future development in the organization, it is important for them to follow the organization's norms and requirements in order to increase their visibility, identity, and status in the organization. In addition, complying with environmental and resource maintenance requirements is not only beneficial to the employees themselves, it is also conducive to the long-term development of the organization in line with corporate social responsibility. Therefore, we propose the following:

Hypothesis 3. Green display rules moderate the relationship between new generation employees' work values and green behavior.

\section{Method}

\subsection{Procedure}

We contacted human resources managers to inquire as to whether they were willing to take part in our study, and four enterprises in China agreed. The data were collected at two time points. At Time 1, potential participants received an unsealed envelope that contained a cover letter explaining the purpose and procedure of this study and assuring confidentiality, and a copy of the survey form. They were requested to provide informed consent and were assigned a unique code that allowed us to match the data collected from them later at Time 2. During the first data collection, 783 respondents completed the survey, including scales of work values, green display rules, and personal information. Respondents were requested to put the completed survey forms into the envelopes, seal them, and send back to us. Four weeks later, at Time 2, all 783 employees were contacted to complete the second survey in order to assess their felt accountability and green behavior. Out of 783 millennial-generation white-collar employees, 567 provided usable responses.

\subsection{Participants}

The 567 participants were from four Chinese companies in the information technology (23\%), telecommunication $(18 \%)$, financial $(23 \%)$, and service $(36 \%)$ industries, respectively; $56 \%$ of the employees were male and $44 \%$ were female. Participants' ages ranged from 22 to 38 years $(M=28.3$, $\mathrm{SD}=6.33$ ). These participants were born from the 1980s to 2000, known as millennials, or the 'New Generation' $[21,22,35]$. Being born under the one-child policy in China (since 1980) has made Chinese millennials behave differently from older generations in China and millennials in other countries and demonstrate different characteristics, such as having a strong need for self-improvement and a stronger awareness of their contributions at work and at home [35]. Out of them, all received a bachelor's degree or above. They had a mean job tenure of 6.63 years (standard deviation $=5.17$ years) and $24 \%$ of them were supervisors.

\subsection{Measures}

The survey was conducted in Chinese after being translated from the initial English scales. To ensure the accuracy of the measures, we adopted the translate-back-translate procedure [50]. 
New generation employees' work values. The 20-item work values scales developed by Hou et al. [23] were incorporated to measure the work values of Chinese new generation employees, including five dimensions (utilitarian orientation, intrinsic preference, interpersonal harmony, innovative orientation, and long-term development), and each dimension comprised four items and was measured using a 5 -point Likert scale ( $1=$ very unimportant to $5=$ very important).

A sample item of utilitarian orientation is "How important is increasing compensation for you?" The Cronbach's $\alpha$ in this study was 0.83 . A sample item of intrinsic preference is "How important is your job consistent with your own interests for you?" The Cronbach's $\alpha$ in this study was 0.87 . A sample item of interpersonal harmony is "How important is working in a harmonious environment for you?" The Cronbach's $\alpha$ in this study was 0.82 . A sample item of innovative orientation is "How important is working in a challenging environment for you?" The Cronbach's $\alpha$ in this study was 0.84 . A sample item of long-term orientation is "How important is a desirable career perspective for you?" The Cronbach's $\alpha$ in this study was 0.87 .

Felt accountability. We adopted the eight-item scale developed by Hall et al. [43] to measure employees' felt accountability, using a 7-point Likert scale ( $1=$ strongly disagree to $5=$ strongly agree). A sample item is "I am held very accountable for my actions regarding environmental maintenance and resource recycling at work." The Cronbach's $\alpha$ in this study was 0.74 .

Green display rules. We developed a three-item scale of green display rules to measure employees' perceived level of green display rules by adapting Hochschild's [51] display rule demands and Kim et al.'s [1] work group green advocacy measurement, using a 6-point Likert scale $(1=$ "never" to $6=$ "always"). A sample item is "We are required to reduce, reuse, and recycle office supplies in the workplace." Complete scale items can be found in the Appendix A. The Cronbach's $\alpha$ in this study was 0.80 .

Voluntary green workplace behavior. We adopted the six-item scale developed by Kim et al. [1] to measure new generation employees' voluntary green workplace behavior, using a 6-point Likert scale ( $1=$ "never" to $6=$ "always"). A sample item is "I avoid unnecessary printing to save papers" and "I recycle reusable things in the workplace". The Cronbach's $\alpha$ in this study was 0.78 .

Control variables. As individual demographic characteristics, such as gender, age, and tenure, have proved in previous studies [23] to be effective predictors of employee extra-role performance, we controlled for each of these variables. Age and tenure were measured in years, and gender was coded as $1=$ male and $2=$ female.

\subsection{Data Analysis}

We employed hierarchical regression analysis using SPSS 22.0 and Amos 17.0 to test the main effect of employees' work values on voluntary green behavior, and the moderating effect of green display rules on the relationship between them. The measurement instrument was validated following Boiral \& Paillé's suggestions [52]. First, confirmatory factor analyses (CFA) were conducted to validate the factor structure. The baseline measurement model (Model 1 in Table 1), into which all study variables were loaded in their respective categories (i.e., utilitarian orientation, intrinsic preference, interpersonal harmony, innovative orientation, long-term development, felt accountability, green display rules, and green behavior), was formed. Then, utilitarian orientation, intrinsic preference, interpersonal harmony, innovative orientation, and long-term development were combined into one factor (since these five factors are the dimensions of work values); therefore, the four-factor model (Model 2 in Table 1) was also formed, followed by a three-factor model (Model 3 in Table 1) which combined utilitarian orientation, intrinsic preference, interpersonal harmony, innovative orientation, and long-term development into one factor, and felt accountability and green display rules into another. In addition, the other three factors (felt accountability, green display rules, and green behavior) were also combined into one factor, resulting in the two-factor model (Model 4 in Table 1). Finally, all factors were combined into a one-factor model (Model 5 in Table 1). These five models were examined through a series of indices for assessing the construct validity of the measures. The goodness-of-fit 
indices adopted in the model were $\chi^{2}$, the root mean square error of approximation (RMSEA), the standardized root mean square residual (SRMR), the Tucker-Lewis index (TLI), and the comparative fit index (CFI). We evaluated model fit using CFI, RMSEA, and SRMR as suggested by Hu and Bentler [53]. The cutoff for CFI is 0.90 or more, and the cutoff for RMSEA and SRMR is 0.80 or less. Table 2 presents the correlations, means, and standard deviations of the study variables.

\section{Results}

Following Aiken and West [54], a hierarchical regression model was employed to verify the proposed hypotheses. Demographic variables such as gender $(0=$ female and $1=$ male $)$, age, job tenure (years), and job position ( $0=$ subordinate, $1=$ supervisor), were included in the analysis as controls. The hypothesized model using confirmatory factor analysis exhibited a good fit to the data as shown in Table 1. The hypotheses about the moderating effects of green display rules and the mediating effect of felt accountability were subsequently verified (Tables 3 and 4). In addition, the effect of work values on green behavior under the influence of varying degrees of green displayed rules was illustrated (Figures 2-4).

\subsection{Common Method Variance Check}

Our data collection strategy of measuring constructs at different points in time and the multilevel nature of our model mitigated some concerns that arise in studies that rely on survey data. Besides, according to Harris and Mossholder's [55] perspective, the valid theoretical model in this study could partially exclude common method variance. Overall, our strategy of collecting data at different points in time and the cross-level nature of our model helped minimize the likelihood that common method variance accounts for the substantive findings or the observed relationships among the variables.

Table 1. Measurement models test.

\begin{tabular}{|c|c|c|c|c|c|c|c|}
\hline Models & $x^{2}$ & $d f$ & $\Delta x^{2}$ & RMSEA & SRMR & TLI & CFI \\
\hline $\begin{array}{l}\text { 1. Baseline model (including UO, IP, IH, IO, } \\
\text { LTD, FA, GDR, GB) }\end{array}$ & 1479.12 & 601 & - & 0.06 & 0.05 & 0.91 & 0.92 \\
\hline $\begin{array}{l}\text { 2. Four-factor model (combining UO, IP, IH, } \\
\text { IO, and LTD into one factor) }\end{array}$ & 1516.67 & 623 & $37.55^{* * *}$ & 0.08 & 0.07 & 0.90 & 0.90 \\
\hline $\begin{array}{l}\text { 3. Three-factor model (combining UO, IP, } \\
\text { IH, IO, and LTD into one factor; FA and } \\
\text { GDR into one factor) }\end{array}$ & 1691.12 & 626 & $211.98^{* * *}$ & 0.15 & 0.15 & 0.85 & 0.86 \\
\hline $\begin{array}{l}\text { 4. Two-factor model (combining UO, IP, IH, } \\
\text { IO, and LTD into one factor; FA, GDR, and } \\
\text { GB into one factor) }\end{array}$ & 1843.33 & 628 & $364.21^{* * *}$ & 0.19 & 0.18 & 0.80 & 0.77 \\
\hline $\begin{array}{l}\text { 5. One-factor model (combining all the } \\
\text { items into one factor) }\end{array}$ & 2012.91 & 629 & $533.79^{* * *}$ & 0.22 & 0.20 & 0.73 & 0.71 \\
\hline
\end{tabular}

Table 2. Means, standard deviations, correlations, and reliability among study variables.

\begin{tabular}{|c|c|c|c|c|c|c|c|c|c|c|c|c|c|}
\hline Variables & $\mathbf{M}$ & SD & 1 & 2 & 3 & 4 & 5 & 6 & 7 & 8 & 9 & 10 & 11 \\
\hline 1. Gender & 0.56 & 0.50 & - & & & & & & & & & & \\
\hline 2. Age & 28.3 & 6.33 & 0.12 & - & & & & & & & & & \\
\hline 3. Job tenure & 6.63 & 5.17 & $0.20 *$ & $0.43^{* * *}$ & - & & & & & & & & \\
\hline 4. Utilitarian orientation & 3.56 & 0.53 & $0.18^{*}$ & 0.10 & $0.19^{*}$ & $(0.83)$ & & & & & & & \\
\hline 5. Intrinsic preference & 4.11 & 0.46 & 0.12 & 0.12 & 0.11 & $0.43^{* * *}$ & $(0.87)$ & & & & & & \\
\hline 6. Interpersonal harmony & 3.81 & 0.50 & $-0.20^{*}$ & $0.18^{*}$ & $0.18^{*}$ & $0.38^{* * *}$ & $0.45^{* * *}$ & $(0.82)$ & & & & & \\
\hline 7. Innovative orientation & 3.97 & 0.69 & 0.16 & 0.13 & 0.07 & $0.31 * *$ & $0.40^{* * *}$ & $0.30^{* *}$ & $(0.84)$ & & & & \\
\hline 8. Long-term development & 4.01 & 0.44 & $0.23 * *$ & 0.15 & $0.20^{*}$ & $0.36^{* * *}$ & $0.42^{* * *}$ & $0.38^{* * *}$ & $0.34^{* * *}$ & $(0.87)$ & & & \\
\hline 9. Felt accountability & 4.41 & 1.12 & 0.08 & 0.04 & 0.07 & 0.13 & $0.24 * *$ & $0.26^{* *}$ & $0.20 *$ & $0.31^{* * * *}$ & $(0.74)$ & & \\
\hline 10. Green display rules & 3.37 & 0.89 & 0.04 & 0.12 & 0.15 & 0.18 * & $0.21 *$ & $0.27^{* *}$ & 015 & $0.25^{* *}$ & $0.31^{* *}$ & $(0.80)$ & \\
\hline 11. Green behavior & 3.72 & 0.71 & -0.03 & 0.09 & 0.13 & 0.16 & $0.26^{* *}$ & $0.22 *$ & $0.18 *$ & $0.28^{* *}$ & $0.35^{* * *}$ & $0.33^{* * *}$ & $(0.78)$ \\
\hline
\end{tabular}




\subsection{Hypothesis Examination}

In Hypothesis 1, we proposed that new generation employees' work values would be positively related to their voluntary green workplace behaviors. As illustrated in Table 3, the positive effects of four of the five work values measures were supported $(p<0.01)$ with the exception of utilitarian orientation.

Table 3. Hierarchical regression models: The moderating effect of green display rules and the mediating effect of felt accountability.

\begin{tabular}{|c|c|c|c|c|c|c|c|}
\hline \multirow[b]{2}{*}{ Models } & \multirow[b]{2}{*}{$\begin{array}{c}\text { Model } 1 \\
\beta\end{array}$} & \multirow[b]{2}{*}{$\begin{array}{c}\text { Model } 2 \\
\beta\end{array}$} & \multicolumn{2}{|c|}{ Green Behavior } & \multirow[b]{2}{*}{$\begin{array}{c}\text { Model } 5 \\
\beta\end{array}$} & \multicolumn{2}{|c|}{ Felt Accountability } \\
\hline & & & $\begin{array}{c}\text { Model } 3 \\
\beta\end{array}$ & $\begin{array}{c}\text { Model } 4 \\
\beta\end{array}$ & & $\begin{array}{c}\text { Model } 6 \\
\beta\end{array}$ & $\begin{array}{c}\text { Model } 7 \\
\beta\end{array}$ \\
\hline \multicolumn{8}{|l|}{ Control variables } \\
\hline Gender & 0.10 & 0.08 & .09 & 0.08 & 0.12 & 0.11 & 0.10 \\
\hline \multicolumn{8}{|l|}{ Age } \\
\hline Post-90s vs. post- 80 s & $0.17 *$ & 0.15 & 0.13 & 0.14 & 0.14 & 0.03 & 0.02 \\
\hline Post-00s vs. post- $80 \mathrm{~s}$ & $0.18^{*}$ & $0.17 *$ & 0.15 & 0.15 & $0.16^{*}$ & -0.03 & -0.05 \\
\hline Job tenure (years) & 0.12 & 0.08 & 0.09 & 0.07 & 0.08 & 0.05 & 0.03 \\
\hline Position & $0.23 * *$ & $0.22 * *$ & $0.22 * *$ & $0.19 *$ & $0.23 * * *$ & $0.26^{* * *}$ & $0.22 * * *$ \\
\hline \multicolumn{8}{|l|}{ Independent variables } \\
\hline Utilitarian orientation (UO) & & 0.13 & 0.07 & 0.10 & 0.09 & & 0.11 \\
\hline Intrinsic preference (IP) & & $0.23^{* *}$ & $0.18^{*}$ & $0.19 *$ & $0.20 *$ & & $0.21^{* *}$ \\
\hline Interpersonal harmony $(\mathrm{IH})$ & & $0.29 * * *$ & $0.22 * *$ & $0.22 * *$ & $0.23^{* *}$ & & $0.25^{* *}$ \\
\hline Innovative orientation (IO) & & $0.16^{*}$ & 0.13 & 0.14 & 0.12 & & $0.20^{* *}$ \\
\hline Long-term development (LTD) & & $0.31^{* * *}$ & $0.26^{* *}$ & $0.25^{* *}$ & $0.25^{* *}$ & & $0.36^{* * *}$ \\
\hline Felt accountability & & & $0.33^{* * *}$ & $0.32 * * *$ & $0.30^{* * *}$ & & \\
\hline Green display rules & & & & $0.30^{* * *}$ & $0.27 * *$ & & \\
\hline \multicolumn{8}{|l|}{ Moderating variables } \\
\hline Green display rules $\times$ UO & & & & & 0.10 & & \\
\hline Green display rules $\times$ IP & & & & & $0.16^{*}$ & & \\
\hline Green display rules $\times \mathrm{IH}$ & & & & & $0.21 * *$ & & \\
\hline Green display rules $\times \mathrm{IO}$ & & & & & 0.07 & & \\
\hline Green display rules $\times$ LTD & & & & & $0.24 * *$ & & \\
\hline $\mathrm{R}^{2}$ & 0.151 & 0.174 & 0.186 & 0.196 & 0.204 & 0.160 & 0.184 \\
\hline$\Delta \mathrm{R}^{2}$ & - & $0.23^{* * *}$ & $0.12 * * *$ & $0.10^{* * *}$ & $0.08^{*}$ & & $0.24^{* * *}$ \\
\hline
\end{tabular}

Note, $\mathrm{n}=567,{ }^{*} p<0.05,{ }^{* * *} p<0.01,{ }^{* * *} p<0.001$. Gender: $0=$ female and $1=$ male. Position: $0=$ subordinate and 1 = supervisor.

Table 4. Bootstrapping tests for mediating effect of felt accountability.

\begin{tabular}{lcc}
\hline \multicolumn{1}{c}{ Indirect Paths } & Indirect Effect & 95\% CI \\
\hline Utilitarian orientation $\rightarrow$ felt accountability $\rightarrow$ Green behavior & 0.04 & {$[-0.12,0.08]$} \\
Intrinsic preference $\rightarrow$ felt accountability $\rightarrow$ Green behavior & 0.07 & {$[0.01,0.13]$} \\
Interpersonal harmony $\rightarrow$ felt accountability $\rightarrow$ Green behavior & 0.08 & {$[0.06,0.18]$} \\
Innovative orientation $\rightarrow$ felt accountability $\rightarrow$ Green behavior & 0.07 & {$[0.00,0.11]$} \\
Long-term development $\rightarrow$ felt accountability $\rightarrow$ Green behavior & 0.12 & {$[0.08,0.23]$} \\
\hline
\end{tabular}

Note, $\mathrm{n}=567$. CI = Confidence interval. CI values do not include zero at three decimal places. Bootstrapping is conducted on the basis of the Monte Carlo method with 10,000 repetitions.

In Hypothesis 2, we argued that felt accountability would mediate the relationship between new generation employees' work values and voluntary green workplace behaviors. To examine the mediating effect of felt accountability, we followed Baron and Kenny's [56] and Preacher, Rucker, and Hayes' [57] procedures. As shown in Table 4, out of five work values, intrinsic preference, interpersonal harmony, innovative orientation, and long-term development had significant indirect effects on green behavior.

In Hypothesis 3, we assumed that green display rules would positively moderate the relationship between new generation employees' work values and their voluntary green workplace behaviors. Results in Table 3 (Models 4 and 5) show that the effects of new generation employees' work values (i.e., intrinsic preference, interpersonal harmony, and long-term development) on their voluntary green workplace behaviors varied when employees perceived a differing degree of green display rules. A simple slope was used to further examine the moderating effect [54]. As shown in Figure 2, when the 
level of perceived green display rules was high, the positive relationship between intrinsic preference and green behavior was significant; when the level of green display rules was low, the positive relationship between intrinsic preference and green behavior was also significant. This suggests that employees' intrinsic preferences have a stronger effect on their voluntary green workplace behaviors when they perceived a higher degree of green display rules; when the perceived level of green display rules was low, the effect of intrinsic preference on voluntary green workplace behaviors became weaker. Similarly, as Figure 3 shows, when the level of green display rules was high, the positive relationship between interpersonal harmony and green behavior was strengthened; when the level of green display rules was low, the positive effect of interpersonal harmony on green behavior was lessened. As displayed in Figure 4, when the level of green display rules was high, the work value of long-term development had a stronger effect on green behavior; when the level of green display rules was low, the positive relationship between long-term development and green behavior was also lessened. Thus, Hypothesis 3 was supported except for utilitarian and innovative orientation values.

In addition, to assess the potential issues with multicollinearity, variance inflation factor (VIF) tests were run for all models in Table 3. In all the cases, the mean was below the suggested level (i.e., 2.1) at which problems can occur [58]. Second, the correlations between all variables in the model were relatively small and were well below 0.80 at which multicollinearity may be considered a problem [59]. The correlation matrix can be found in Table 2 .

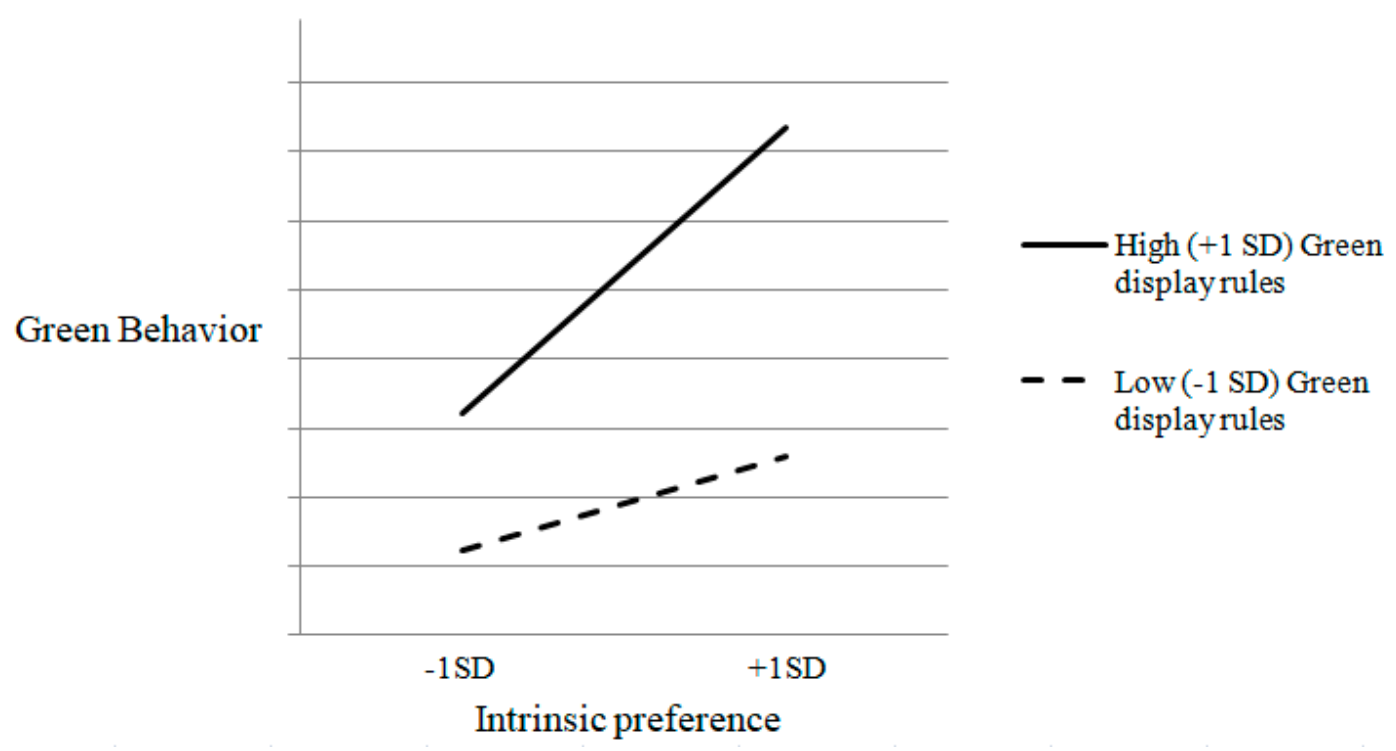

Figure 2. Moderating effect of green display rules on the relationship between intrinsic preference and green behavior. 


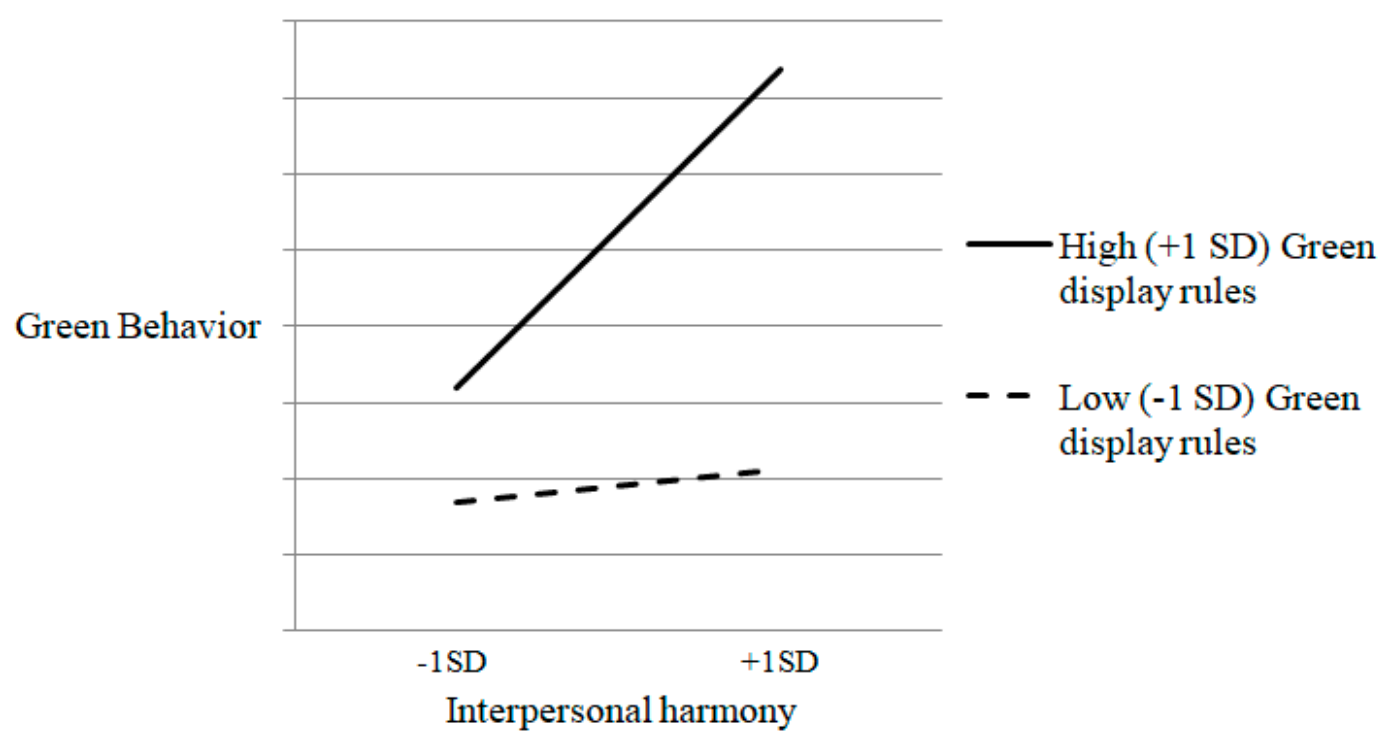

Figure 3. Moderating effect of green display rules on the relationship between interpersonal harmony and green behavior.

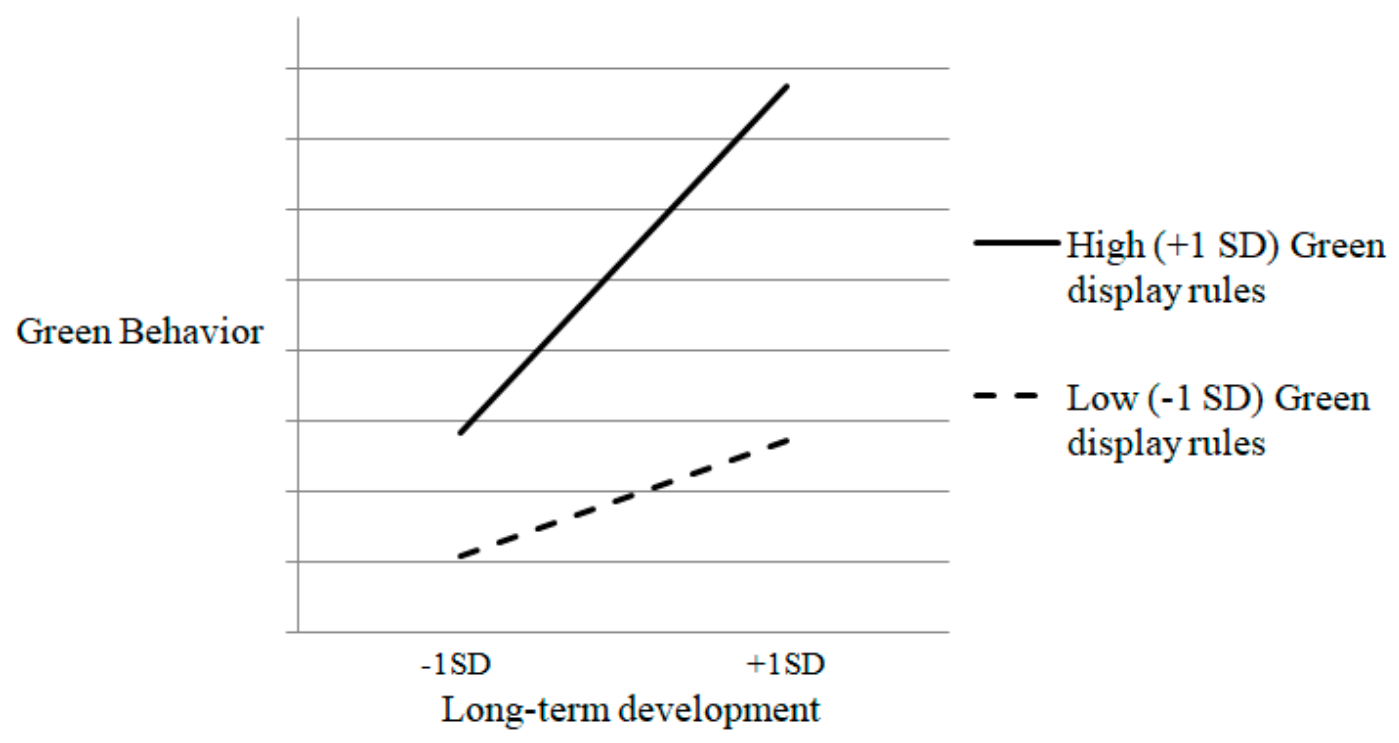

Figure 4. Moderating effect of green display rules on the relationship between long-term development and green behavior.

\section{Discussion}

The research results showed that except for utilitarian orientation, new generation employees' work values of intrinsic preference, interpersonal harmony, innovative orientation, and long-term development had a significant and positive influence on voluntary green workplace behavior. This is consistent with Hou and Lu's [25] and Swann et al.'s [41] suggestions that the work values of intrinsic preferences, innovative orientation, and interpersonal harmony encourage new generation employees to maintain their positive self-views and work in a manner that is consistent with their positive self-views, which lead to interpersonal altruism in the workplace and in turn promote their prosocial behavior (i.e., green behavior). Moreover, our research finding aligns with the argument that individual employees with long-term development values are likely to engage in green behavior, in order to maintain stable team relations, and strengthen their positive self-views [23]. Nevertheless, our results did not support a significant relationship between utilitarian orientation work value and green behavior. This is probably because millennial-generation employees with a utilitarian 
orientation work value may focus more on their in-role performance in order to attain material goods or benefits [60], instead of participating in green behavior, which may not generate immediate benefits for them. Specifically, utilitarian orientation has a stronger impact on in-role performance than it does on extra-role performance [16]. Compared to high extra-role performance, which benefits employees' indirect and invisible interests, superior in-role performance increases immediate interests, such as higher salary and bonuses [23]. Therefore, utilitarian employees are highly motivated to focus on in-role performance, rather than prosocial behaviors.

The results of the moderating effect of green display rules on the relationship between new generation employees' work values and their voluntary green workplace behaviors confirmed our argument that display rules play an important role in activating values and strengthening or weakening values-to-behavior relationships [15,49]. The possible reason why the moderating effects of green display rules on the relationships between utilitarian and innovative orientation work values and their voluntary green workplace behaviors were not significant is possibly because of the value inconsistency. As described previously, employees with a utilitarian orientation work value tend to pay more attention to the realization of their own interests and values. The so-called value realization is based on achieving their own internal preferences and interests, rather than gaining recognition and respect from others by helping people or meeting organizational norms and requirements. Similarly, employees with an innovative orientation work value may have the tendency to challenge the tradition [16]. While the Chinese cultures emphasize the value of tradition and harmony, an innovative-oriented employee may find it hard to fit in a working environment that requires employees to follow specific rules in order to regulate their green-related behaviors. As a result, they neglect the social cues from their external environment-organization or group (the emphasis on and requirements for environmental protection and resource recycling, and, hence, they would be less likely to engage in prosocial green behaviors).

Organizations are increasingly being pressured to improve their environmental performance. Evidence from our research suggests that including felt accountability and green display rules may contribute to employees' voluntary green workplace behaviors. For example, when an organization's website or virtual bulletin board publishes the rules and requirements for environmental protection and resource recycling, new generation employees who pay attention to their own preferences and interests can be more aware of their work values and job requirements, and in turn are more likely to comply with the display rules.

The new generation of employees was born in the era of environmental awareness and resource conservation. Enterprises nowadays no longer consider pursuing profits as their primary goals. Instead, they pay attention to issues related to environmental protection and resource recovery. Although the behaviors of new generation employees are more likely to be driven by their own interests and preferences, their values are also deeply influenced by contemporary social, economic, and environmental changes. Therefore, the work values of the new generation employees are rooted in a high degree of environmental awareness, and thus they are more likely to display green behaviors.

\section{Limitations and Directions for Future Research}

Of course, this study is only one step forward in the search for knowledge about how to promote environmentally friendly behavior in the workplace. Given the increasing and diverse forms of environmental degradation, additional research is indeed needed. First, the ability to generalize from this research is limited as the subjects in this study came from a single country (i.e., not including a cross-cultural sample), albeit with a strong cultural focus. Our suggestion for future research is to test the generalizability of our research findings. In addition to differences in the cultural, regulatory, and physical environments that differentially affect companies in different countries, research indicates that environmental beliefs, knowledge, and attitudes vary around the world [61]. For example, in Western countries such as the United States, environmental values are linked with altruistic concepts which run counter to traditional values, while in Asian countries such as Japan, environmental values are strongly related to traditional values [61]. Second, our study was limited to investigating the effects 
of individual factors (i.e., at the micro level) on employee pro-environmental behaviors. Therefore, research also is needed to improve our understanding of how contextual differences at the macro level influence voluntary green workplace behavior. For example, future research in other institutional contexts may yield different results. Third, this research focused on voluntary green behaviors in the workplace related to individual work values and, as such, was dependent on the organizational setting [37]. The findings are, therefore, unable to address questions regarding how individuals engage in different types of pro-environmental behaviors and consistency across different settings [62]. Fourth, our measure of voluntary green behaviors in the workplace was somewhat limited in scope, as acknowledged in Kim et al. [1]. More comprehensive measures of green behavior are needed to further improve the insights. Therefore, we encourage future research that tests the robustness of our findings by using alternative forms of measurement [9]. In addition, it would be worth verifying the cross-cultural applicability of the millennial generation's work values and its impact on individual outcomes. Finally, applying alternative data collection methods (e.g., objective indices of environmental performance metrics) would allow for stronger conclusions to be drawn about our model's robustness.

\section{Conclusions}

Drawing on self-verification theory [32,33,41] and social information perspectives [34], this study examined the main effect of new generation employees' work values on their voluntary green workplace behaviors, as well as exploring the mediation effect of felt accountability and the moderating effect of green display rules on the relationship between them. The findings deepened our understanding of the relationship between Chinese millennial employees' work values and their voluntary green workplace behaviors. For example, while organizations are increasingly being pressured to improve their environmental performance, evidence from our research suggests that displaying green rules may contribute to employees' voluntary green workplace behaviors by raising employees' awareness of their work values and social norms. Given the Chinese workforce is the largest in the world and millennials have become an important part of this workforce, this study can provide international human resource managers with valuable information, helping them encourage employees' green behaviors in the workplace.

Author Contributions: Conceptualization, K.-S.Y. and P.-J.W.; methodology, K.-S.Y.; software, K.-S.Y.; validation, K.-S.Y., P.-J.W. and T.J.W.; formal analysis, K.-S.Y.; investigation, T.J.W.; resources, T.J.W.; data curation, K.-S.Y.; writing — original draft preparation, P.-J.W.; writing—review and editing, P.-J.W.; visualization, K.-S.Y.; supervision, P.-J.W.; project administration, P.-J.W.; funding acquisition, P.-J.W. and T.J.W.

Funding: This research was supported by the Scientific Research Fund of Huaqiao University (19SKBS106), and National Natural Science Foundation of China (71702059).

Acknowledgments: The authors are grateful to the valuable comments made by the editor and reviewers.

Conflicts of Interest: The authors declare no conflict of interest.

\section{Appendix A}

Adapted Scales of Green Display Rules [43]

1. We are required to reduce, reuse, and recycle office supplies in the workplace.

2. The company encourages workplace pro-environmental behaviors.

3. The company expects us to share knowledge, information, and ways to reduce waste of workplace resources or environmental damage.

\section{References}

1. Kim, A.; Kim, Y.; Han, K.; Jackson, S.E.; Ployhart, R.E. Multilevel Influences on Voluntary Workplace Green Behavior: Individual Differences, Leader Behavior, and Coworker Advocacy. J. Manag. 2017, 43, 1335-1358. [CrossRef] 
2. Dumont, J.; Shen, J.; Deng, X. Effects of Green HRM Practices on Employee Workplace Green Behavior: The Role of Psychological Green Climate and Employee Green Values. Hum. Resour. Manag. 2017, 56, 613-627. [CrossRef]

3. Ones, D.S.; Dilchert, S. Employee Green Behaviors. In Managing Human Resources for Environmental Sustainability; Jackson, S.E., Ones, D.S., Dilchert, S., Eds.; Jossey-Bass: San Francisco, CA, USA, 2012; pp. 85-116.

4. Aguinis, H.; Glavas, A. What We Know and Don'T Know about Corporate Social Responsibility: A Review and Research Agenda. J. Manag. 2012, 38, 932-968. [CrossRef]

5. Salem, M.A.; Hasnan, N.; Osman, N.H. Environmental Issues and Corporate Performance: A Critical Review. J. Environ. Earth Sci. 2012, 2, 112-122.

6. Wee, S.Y.; Quazi, H. Development and Validation of Critical Factors of Environmental Management. Indus. Manag. Data Syst. 2015, 105, 96-114.

7. Ramus, C.A.; Steger, U. The Roles of Supervisory Support Behavior and Environmental Policy in Employee "Eco-Initiatives" at Leading-edge European Companies. Acad. Manag. J. 2000, 43, 605-626.

8. Daily, B.F.; Bishop, J.W.; Govindarajulu, N. A Conceptual Model for Organizational Citizenship Behavior Directed toward the Environment. Bus. Soc. 2009, 48, 243-256. [CrossRef]

9. Francoeur, V.; Paille, P.; Yuriev, A.; Boiral, O. The Measurement of Green Workplace Behaviors: A Systematic Review. Organ. Environ. 2019, 1-25. [CrossRef]

10. Boiral, O. Greening the Corporation through Organizational Citizenship Behaviors. J. Bus. Ethics 2009, 87, 221-236. [CrossRef]

11. Yuriev, A.; Boiral, O.; Francoeur, V.; Paille, P. Overcoming the barriers to pro-environmental behaviors in the workplace: A systematic review. J. Clean. Prod. 2018, 182, 379-394. [CrossRef]

12. Bamberg, S.; Möser, G. Twenty Years after Hines, Hungerford, and Tomera: A New Meta-analysis of Psycho-Social Determinants of Pro-environmental Behavior. J. Environ. Psychol. 2007, 27, 14-25. [CrossRef]

13. Morton, N.; Hill, C.; Meiring, D. Validating the South African Personality Inventory (SAPI): Examining Green Behavior and Job Crafting within a Nomological Network of Personality. Int. J. Pers. Psychol. 2018, 4, 25-38.

14. Shao, P.; Resick, C.J.; Hargis, M.B. Helping and Harming Others in the Workplace: The Roles of Personal Values and Abusive Supervision. Hum. Relat. 2011, 64, 1051-1078. [CrossRef]

15. Verplanken, B.; Holland, R.W. Motivated Decision Making: Effects of Activation and Self-Centrality of Values on Choices and Behavior. J. Personal. Soc. Psychol. 2002, 82, 434-447. [CrossRef]

16. Lin, Y.; Li, Y.; Hou, X. Utilitarian Orientation, Long-term Orientation, and Performance: Evidence from Chinese Millennial-generation Employees. Soc. Behav. Personal. Int. J. 2015, 43, 1463-1476. [CrossRef]

17. Dose, J.J. Work Values: An Integrative Framework and Illustrative Application to Organizational Socialization. J. Occup. Organ. Psychol. 1997, 70, 219-240. [CrossRef]

18. Becker, G.M.; McClintock, G.G. Value: Behavioral Decision Theory. Annu. Rev. Psychol. 1967, 18, $239-286$. [CrossRef] [PubMed]

19. Elizur, D. Facets of Work Values: A Structural Analysis of Work Outcomes. J. Appl. Psychol. 1984, 69, 379-389. [CrossRef]

20. Elizur, D.; Borg, I.; Hunt, R.; Beck, I.M. The Structure of Work Values: A Cross Cultural Comparison. J. Organ. Behav. 1991, 12, 21-38. [CrossRef]

21. Yi, X.; Ribbens, B.; Fu, L.; Cheng, W. Variation in Career and Workplace Attitudes by Generation, Gender, and Culture Differences in Career Perceptions in the United States and China. Empl. Relat. 2015, 37, 66-82. [CrossRef]

22. Sirota, D.; Klein, D. The Enthusiastic Employee: How Companies Profit by Giving Workers What They Want; Pearson Education: Upper Saddle River, NJ, USA, 2013.

23. Hou, X.; Li, Y.; Tu, Y. Work Values of Chinese Millennial Generation: Structure, Measurement and Effects on Employee Performance. Acta Psychol. Sin. 2014, 46, 823-840. [CrossRef]

24. Jiang, X.; Yang, J. Understanding the Work Values of Chinese Employees. Psychology 2011, 2, 579-583. [CrossRef]

25. Hou, X.; Lu, F. Effects of Work Values of Millennial Employees, Intrinsic Motivation on Job Performance: The Moderating Effect of Organizational Culture. Manag. Rev. 2018, 30, 157-168.

26. Li, Y.P.; Tu, Y.D. Value Orientation of Organizational Citizenship Behavior. Manag. World 2012, 5, 1-7. 
27. Hall, A.T.; Frink, D.D.; Buckley, M.R. An Accountability Account: A Review and Synthesis of The Theoretical and Empirical Research on Felt Accountability. J. Organ. Behav. 2017, 38, 204-224. [CrossRef]

28. Schlenker, B.R.; Britt, T.W.; Pennington, J.; Murphy, R.; Doherty, K. The Triangle Model of Responsibility. Psychol. Rev. 1994, 101, 632-652. [CrossRef] [PubMed]

29. Schlenker, B.R.; Weigold, M.F.; Doherty, K. Coping with Accountability: Self-identification and Evaluative Reckonings. In Handbook of Social and Clinical Psychology; Snyder, C.R., Forsyth, D.R., Eds.; Pergamon: New York, NY, USA, 1991; pp. 96-115.

30. Zaval, L.; Markowitz, E.M.; Weber, E.U. How will I be remembered? Conserving The Environment for The Sake of One'S Legacy. Psychol. Sci. 2015, 26, 231-236. [CrossRef] [PubMed]

31. Eom, K.; Kim, H.S.; Sherman, D.K.; Ishii, K. Cultural Variability in the Link between Environmental Concern and Support for Environmental Action. Psychol. Sci. 2016, 27, 1331-1339. [CrossRef] [PubMed]

32. Swann, W.B., Jr. Self-verification: Bringing Social Reality into Harmony with the Self. In Social Psychological Perspectives on the Self; Suls, J., Greenwald, A.G., Eds.; Hillsdale: New Jersey, NJ, USA, 1983; Volume 2, pp. 33-66.

33. Swann, W.B., Jr. To be Adored or to be Known? The Interplay of Self-enhancement and Self-Verification. In Handbook of Motivation and Cognition: Foundations of Social Behavior; Higgins, E., Sorrentino, R., Eds.; Guilford Press: New York, NY, USA, 1990; pp. 408-448.

34. Salancik, G.R.; Pfeffer, J. A Social Information Processing Approach to Job Attitudes and Task Design. Adm. Sci. Q. 1978, 23, 224-253. [CrossRef] [PubMed]

35. Zhao, Y. Managing Chinese Millennial Employees and Their Impact on Human Resource Management Transformation: An Empirical Study. Asian Pac. Bus. Rev. 2018, 24, 472-489. [CrossRef]

36. Parry, E.; Urwin, P. Generational Differences in Work Values: A Review of Theory and Evidence. Int. J. Manag. Rev. 2011, 13, 79-96. [CrossRef]

37. Norton, T.A.; Parker, S.L.; Zacher, H.; Ashkanasy, N.M. Employee Green Behavior: A Theoretical Framework, Multilevel Review, and Future Research Agenda. Organ. Environ. 2015, 28, 103-125. [CrossRef]

38. Bardi, A.; Schwartz, S.H. Values and behavior: Strength and Structure of Relations. Personal. Soc. Psychol. Bull. 2003, 29, 1207-1220. [CrossRef] [PubMed]

39. Dolan, S.; Garcia, S.; Richley, B. Managing by Values: A Corporate Guide to Living, Being Alive, and Making a Living in the 21st Century; Palgrave-Macmillan: London, England, 2007.

40. Kilmann, R.H. Toward A Unique/Useful Concept of Values for Interpersonal Behavior: A Critical Review of the Literature on Value. Psychol. Rep. 1981, 48, 939-959. [CrossRef]

41. Swann, W.B., Jr.; Rentfrow, P.J.; Guinn, J.S. Self-verification: The Search for Coherence. In Handbook of Self and Identity; The Guilford Press: New York, NY, USA, 2003; pp. 367-383.

42. Hall, A.T.; Ferris, G.R. Accountability and Extra-role Behavior. Empl. Responsib. Rights J. 2011, 23, $131-144$. [CrossRef]

43. Hall, A.T.; Frink, D.D.; Ferris, G.R.; Hochwarter, W.A.; Kacmar, C.J.; Bowen, M. Accountability in Human Resources Management. In New directions in human resource management; Schriesheim, C.A., Neider, L., Eds.; Greenwich, CT: Houston, TX, USA, 2003; pp. 29-63.

44. Hochwarter, W.A.; Ferris, G.R.; Gavin, M.B.; Perrewé, P.L.; Hall, A.T.; Frink, D.D. Political Skill as Neutralizer of Felt Accountability-Job Tension Effects on Job Performance Ratings: A Longitudinal Investigation. Organ. Behav. Hum. Decis. Process. 2007, 102, 226-239. [CrossRef]

45. Brtek, M.D.; Motowidlo, S.J. Effects of Procedure and Outcome Accountability on Interview Validity. J. Appl. Psychol. 2002, 87, 185-191. [CrossRef] [PubMed]

46. Diefendorff, J.M.; Richard, E.M. Antecedents and Consequences of Emotional Display Rule Perceptions. J. Appl. Psychol. 2003, 88, 284-294. [CrossRef] [PubMed]

47. Wilk, S.L.; Moynihan, L.M. Display Rule "Regulators": The Relationship between Supervisors and Worker Emotional Exhaustion. J. Appl. Psychol. 2005, 90, 917-927. [CrossRef] [PubMed]

48. Zapf, D. Emotion Work and Psychological Well-Being: A Review of the Literature and Some Conceptual Considerations. Hum. Resour. Manag. Rev. 2002, 12, 237-268. [CrossRef]

49. Grant, A.M.; Mayer, D.M. Good Soldiers and Good Actors: Prosocial and Impression Management Motives as Interactive Predictors of Affiliative Citizenship Behaviors. J. Appl. Psychol. 2009, 94, 900-912. [CrossRef] [PubMed] 
50. Brislin, R.W. Translation and Content Analysis of Oral and Written materials. In Handbook of Cross-Cultural Psychology: Methodology; Triandis, H.C., Berry, J.W., Eds.; Allyn \& Bacon: Boston, MA, USA, 1980; Volume 2, pp. 349-444.

51. Hochschild, A.R. The Managed Heart: Commercialization of Human Feeling; University of California Press: Berkeley, CA, USA, 2012.

52. Boiral, O.; Paillé, P. Organizational Citizenship Behavior for the Environment: Measurement and Validation. J. Bus. Ethics 2012, 109, 431-445. [CrossRef]

53. Hu, L.T.; Bentler, P.M. Cutoff Criteria for Fit Indexes in Covariance Structure Analysis: Conventional Criteria versus New Alternatives. Struct. Equ. Model. 1999, 6, 1-55. [CrossRef]

54. Aiken, L.S.; West, S.G. Multiple Regression: Testing and Interpreting Interactions; Sage: Thousand Oaks, CA, USA, 1991.

55. Harris, S.G.; Mossholder, K.W. The Affective Implications of Perceived Congruence with Culture Dimensions during Organizational Transformation. J. Manag. 1996, 22, 527-547. [CrossRef]

56. Baron, R.M.; Kenny, D.A. The Moderator-Mediator Variable Distinction in Social Psychological Research. J. Personal. Soc. Psychol. 1986, 51, 1173-1182. [CrossRef]

57. Preacher, K.J.; Derek, D.D.; Hayes, A.F. Addressing Moderated Mediation Hypotheses: Theory, Methods, and Prescriptions. Multivar. Behav. Res. 2007, 42, 185-227. [CrossRef] [PubMed]

58. Chatterjee, S.; Hadi, A.; Price, B. Regression Analysis by Example, 3rd ed.; John Wiley and Sons: New York, NY, USA, 2000.

59. Studenmund, A.; Cassidy, H. Using Econometrics: A Practical Guide; Little, Brown and Company: Boston, MA, USA, 1987.

60. Hui, C.; Lam, S.S.; Law, K.K. Instrumental Values of Organizational Citizenship Behavior for Promotion: A Field Quasi-experiment. J. Appl. Psychol. 2000, 85, 822-828. [CrossRef] [PubMed]

61. Aoyagi-Usui, M.; Vinken, H.; Kuribayashi, A. Pro-environmental Attitudes and Behaviors: An International Comparison. Hum. Ecol. Rev. 2003, 10, 23-31.

62. Maki, A.; Rothman, A.J. Understanding Pro-environmental Intentions and Behaviors: The Importance of Considering Both the Behavior Setting and the Type of Behavior. J. Soc. Psychol. 2017, 157, 517-531. [CrossRef] [PubMed]

(C) 2019 by the authors. Licensee MDPI, Basel, Switzerland. This article is an open access article distributed under the terms and conditions of the Creative Commons Attribution (CC BY) license (http://creativecommons.org/licenses/by/4.0/). 